RESEARCH ARTICLE

\title{
Elite sorghum (Sorghum bicolor (L.) Moench) hybrids for postrainy season adaptation
}

\author{
Dinakaran Elango* \\ *International Crops Research Institute for the Semi -Arid Tropics, Patancheru, Hyderabad-502 324.
}

Received : $16^{\text {th }}$ April, 2020

Revised : $07^{\text {th }}$ May, 2020

Revised : 26 $6^{\text {th }}$ May, 2020

Accepted : $10^{\text {th }}$ June, 2020

\begin{abstract}
Improving sorghum cultivars for postrainy season adaptation is crucial to ensure food security in dry regions of India. Postrainy season sorghum is primarily used as a food owing to its good grain quality and also the main source of fodder quality especially during dry seasons. Hence, the present investigation was carried out with ten elite sorghum hybrids along with three controls (M 35- 1, Parbhani Moti and CSH 15R) at three locations viz., International Crops Research Institute for the Semi-Arid Tropics (ICRISAT), Mahatma Phule Krishi Vidyapeeth (MPKV) and Marathwada Agricultural University (MAU) during the postrainy season, to identify the best performing sorghum hybrids for postrainy season adaptation. The best performing hybrids for grain yield across three locations were ICSA $502 \times$ SPV 422 (2.4 t ha $\left.^{-1}\right), 8712\left(2.1\right.$ t ha $\left.^{-1}\right)$, ICSA $38 \times$ SPV $422\left(2.1\right.$ t ha $\left.^{-1}\right)$, ICSA $84 \times$ SPV 1411 (2.1 $\left.\mathrm{t} \mathrm{ha}^{-1}\right)$ and XSR401 (2.1 $\left.\mathrm{t} \mathrm{ha}^{-1}\right)$ compared to the control CSH $15 \mathrm{R}(1.8 \mathrm{t}$ ha-1), Parbhani Moti $\left(1.5\right.$ t ha $\left.^{-1}\right)$ and M 35-1 (1.5 t ha $\left.{ }^{-1}\right)$. The selected hybrids were 3 to 4 days earlier than M 35-1 and at par with CSH 15R. Substantial variability observed for 100 seed size (2.4 to $3.5 \mathrm{~g}$ ) and grain luster (score 1 to 2) among the hybrids. The tested hybrids had shootfly dead hearts percentage ranging from 53 to 75 . Based on the number of nodes infected, infection length and percent soft rot, two hybrids (ICSA 675 x SPV 1411 and ICSA 675 x ICSV 700) appeared tolerant to charcoal rot with $<1$ internode infection, length of infection $<5 \mathrm{~cm}$ and $<10 \%$ soft rot.
\end{abstract}

Key words: Charcoal rot resistance; G X E interaction; grain luster; shootfly resistance.

\section{INTRODUCTION}

Sorghum (Sorghum bicolor (L.) Moench) is the fifth most important cereal crop in the world, after rice, wheat, maize and barley (Reddy et al., 2010). It is cultivated in wide geographic areas in the Americas, Africa, Asia and the Pacific. It is the second major crop (after maize) across all agro ecologies in Africa. The grain productivity is about $1.2 \mathrm{t} \mathrm{ha}^{-1}$ in the rainy season in India while it is about $0.8 \mathrm{t} \mathrm{ha}^{-1}$ in postrainy season (ICRISAT, 2011). On the other hand, the global grain productivity is $1.4 \mathrm{t} \mathrm{ha}^{-1}$. The low grain productivity in postrainy sorghum in India is due to several factors. One of the factor is much of the cultivated area is under landraces that are poor grain yielders. Sorghum is grown under receding soil moisture after the cessation of the rainy season. So, end of season drought stress is a major production constraint. Further, low temperature tolerance early in the season, response to photoperiod sensitivity (short day length), flowering and maturity irrespective of temperature fluctuations and sowing dates (thermo-insensitivity), tolerance to shootfly and grain quality traits (bold lustrous grain with thin pericarp) are critical for the postrainy season crop (Reddy et al., 2010).

Due to excellent grain quality, postrainy sorghum crops are used mostly for food. Several varieties like Phule Yashoda, Phule Chitra, Parbhani Moti, Parbhani Jyothi, etc., were released in the recent years by the All India Coordinated Sorghum Improvement Program (AICSIP). However, M 35-1, a landrace selection from Maldandi nearly 75 years ago at Mohol in Maharashtra state during 1937, which has nearly all the traits that are required for the postrainy adaptation. So, M 35-1 is still dominating the varietal scene of postrainy season sorghum areas in India. According to Rao (1970), there is no significant heterosis in postrainy season sorghum and hence for a long time to come, major sorghum genetic enhancement efforts were directed to developing varieties for postrainy season. However, ICRISAT experiments from 1981 to 1987 recorded significant heterosis (Reddy and Stenhouse, 1994), but hybrids lacked shootfly tolerance and grain quality traits, in particular grain luster, compared to M 35-1 (Reddy et al., 2010). In the recent years, AICSIP (All India

$$
107|4-6| 113
$$


Coordinated Sorghum Improvement Program) has been testing hybrids for postrainy season and a few of them were released.

Therefore, in the present study we report the performance of some of the selected postrainy season hybrids for grain yield and other adaptation features and discuss the ways of improving them further for the postrainy season adaptation.

\section{MATERIAL AND METHODS}

A sorghum advanced hybrid trial was conducted with ten hybrids (planted during October month) at ICRISAT- Patancheru(altitude545 m above mean sea level, latitude $17.53^{\circ} \mathrm{N}$ and longitude $78.27^{\circ} \mathrm{E}$ ), MAU- Parbhani (altitude $410 \mathrm{~m}$ above mean sea level, latitude $19^{\circ} 08^{\prime}$ and longitude N 76 ${ }^{\circ}$ ' E) and MPKV- Rahuri (altitude $511 \mathrm{~m}$ above mean sea level, latitude $19^{\circ} 23^{\prime}$ and longitude N 74 $42^{\prime} \mathrm{E}$ ) with three controls (CSH 15R, M 35-1 and Parbhani Moti).Two of the hybrids from private sector were also included in this trial along with the ten test entries. The experimental design was a randomized complete block design with three replications at all three locations. Each plot consisted of four rows, 2 $\mathrm{m}$ long, rows spaced at $45 \mathrm{~cm}$ apart and the plants within rows at $15 \mathrm{~cm}$. Standard agronomic practices and plant protection measures were followed during the growing season. Data were recorded for the hybrids on days to $50 \%$ flowering, plant height, agronomic desirability score, grain size, grain luster, restoration percentage, grain yield, shootfly dead hearts percentage (Atherigonasoccata) and charcoal soft rot score (Macrophominaphaseolina) using standard methods. The agronomic desirability score was taken at maturity on a scale of 1 to 5 , where $1=$ agronomically most desirable and $5=$ least desirable with poor grain and grain luster score was taken at maturity on a scale of 1 to 3 , where 1 = high lustrous; $3=$ non-lustrous. For grain yield, the produce from net plot leaving the border plants was harvested to get the net plot ( 3 sq. $\mathrm{m}$ ) yield and extrapolated to tonnes ha-1.

The data were pooled for three locations to study the mean performance of genotypes and to assess the stability of the genotypes over environments (Eberhart and Russell, 1966) after conducting homogeneity of variance test and analysis was done using GENSTAT $14^{\text {th }}$ edition package of Rothamsted Experiment Station (http://www. vsni.co.uk). Eberhart and Russell (1966) defined a stable genotype as the one which showed high mean yield, regression co-efficient (bi) around unity and deviation from regression near to zero. The regression analysis model is $Y i j=\mu i+\beta i l j+\delta i j$, where $Y_{i j}$ is the variety mean of the $i^{\text {th }}$ variety at the $j^{\text {th }}$ environment, $\mu \mathrm{i}$, is the mean of the $\mathrm{i}^{\text {th }}$ variety over all environments, $\beta i$ is the regression coefficient that measures the response of the $i^{\text {th }}$ variety to varying environments, $\delta \mathrm{ij}$ is the deviation from the regression of the $\mathrm{i}^{\text {th }}$ variety at the $\mathrm{j}^{\text {th }}$ environment, and $\mathrm{l} j$ is the environmental index obtained as the mean of all varieties at the $\mathrm{j}^{\text {th }}$ environment minus the grand mean. Accordingly, the mean and deviation from regression of each genotype were considered for stability and linear regression was used for testing the varietal response.

Genotypes with high mean, bi= 1 with nonsignificant $\delta^{2}$ di are suitable for general adaptation, i.e., suitable over all environmental conditions and they are considered as stable genotypes.

Genotypes with high mean, bi > 1 with nonsignificant $\delta^{2}$ di are considered as below average in stability. Such genotypes tend to respond favourably to better environments but give poor yield in unfavorable environments. Hence, they are suitable for favorable environments.

Genotypes with low mean, bi $<1$ with nonsignificant $\delta^{2}$ di do not respond favourably to improved environmental conditions and hence, it could be regarded as specifically adapted to poor environments.

Genotypes with any bi value with significant $\delta^{2} \mathrm{di}$ are unstable.

\section{RESULTS AND DISCUSSION}

The combined ANOVA depicted significant differences among the genotypes for all the traits except grain luster. Mean squares due to genotype $\mathrm{x}$ environment interaction component showed significance for all the traits studied except plant height (Table 1). Mean squares due to environment (linear) was found significant for most of the characters, indicating differences between environments and their influence on genotypes for expression of these characters (Table 2). This is in accordance with previous reports on Sorghum by Jowett (1972) and Saeed et al. (1987). The environment + (genotype $\mathrm{x}$ environment) was significant for all the characters indicating distinct nature of environments and genotype x environment interactions in phenotypic expression. The genotype $x$ environment (linear) interaction component showed significance for all the characters studied. This indicated significant differences among the genotypes for linear response to environments (bi) and behavior of the genotypes could be predicted over environments more precisely and GxE interaction was outcome of the linear function of environmental components. Hence, prediction of performance of genotypes based on stability parameters would be feasible and reliable. In single environment experiments, $G \times E$ interactions result in an upward bias in the estimation of genetic variances which 
Table 1. Pooled ANOVA for sorghum hybrids for different quantitative traits in postrainy season

\begin{tabular}{|c|c|c|c|c|c|c|}
\hline Source of variation & d.f. & $\begin{array}{r}\text { Days to } 50 \% \\
\text { flowering } \\
\end{array}$ & Plant height (m) & $\begin{array}{r}\text { Grain yield } \\
\left(\mathrm{t} \mathrm{ha}^{-1}\right)\end{array}$ & $\begin{array}{l}100 \text { seed } \\
\text { weight }(\mathrm{g})\end{array}$ & Grain luster \\
\hline Genotype & 12 & $15.18 * *$ & $1261.2 * *$ & $0.66 * *$ & $12.75^{* *}$ & 0.29 \\
\hline Environment & 2 & $13473.05 * *$ & $12141.1 * *$ & $79.52 * *$ & $1967.51 * *$ & 0.57 \\
\hline Environment x Replication & 6 & $2.31 *$ & $1023.4 *$ & $0.28 * *$ & $4.33 * *$ & 0.33 \\
\hline Genotype $\quad x$ Environment & 24 & $7.06 * *$ & 413.2 & $0.90 * *$ & $4.32 * *$ & $0.61 * *$ \\
\hline Error & 72 & 1.00 & 353.1 & 0.52 & 0.97 & 0.19 \\
\hline
\end{tabular}

* Significant at $5 \%$ level ** Significant at $1 \%$ level

leads to discrepancies between expected and realized responses to selection. Effectiveness of selection in a single environment is therefore limited in the presence of significant $\mathrm{G} \times \mathrm{E}$, forcing the breeder to evaluate breeding materials over a diverse range of environments. Strong interactions could even favour breeding for specific adaptation to individual locations within a country (Pham and Edmeades, 1987; Moreno-Gonzáles and Cubero, 1993). In the present study, the significant differences were observed among the hybrids across the three locations for grain yield $\left(\mathrm{t} \mathrm{ha}^{-1}\right)$ and the GxE interactions are significant for all the traits except plant height. The hybrids selected for individual locations were performed across the locations also. This reflected the sourcing of the parents and the hybrids initially for wide adaptation.

Table 2. ANOVA for stability (Eberhart and Russell model) for different quantitative characters

\begin{tabular}{|c|c|c|c|c|c|}
\hline \multirow[b]{2}{*}{ Source } & \multirow[b]{2}{*}{ df } & \multicolumn{4}{|c|}{ Mean sum of squares } \\
\hline & & $\begin{array}{l}\text { Days to } 50 \% \\
\text { flowering }\end{array}$ & $\begin{array}{l}100 \text { seed } \\
\text { weight }(\mathrm{g})\end{array}$ & Grain yield $\left(\mathrm{t} \mathrm{ha}^{-1}\right)$ & Grain luster \\
\hline Genotypes & 12 & $5.13^{* *}$ & $4.25^{* *}$ & $0.22 * *$ & 0.10 \\
\hline $\begin{array}{l}\text { Environment + (Genotypes x } \\
\text { Environments) }\end{array}$ & 26 & $347.64 * *$ & $51.78 * *$ & $2.32 * *$ & $0.20 * *$ \\
\hline Environment (Linear) & 1 & $8982.03 * *$ & $1311.68 * *$ & $53.01 * *$ & 0.38 \\
\hline Variety x Environment (Linear) & 12 & $4.56 * *$ & $1.87 * *$ & $0.31 * *$ & $0.14 * *$ \\
\hline Pooled deviation & 13 & 0.14 & 0.93 & 0.27 & 0.25 \\
\hline Pooled error & & 0.33 & 0.33 & 0.02 & 0.07 \\
\hline
\end{tabular}

* Significant at $5 \%$ level ** Significant at $1 \%$ level

Based on the mean performance across three locations, the best performing hybrids for grain yield were ICSA $502 \times$ SPV $422\left(2.4 \mathrm{t} \mathrm{ha}^{-1}\right), 8712$ (2.1 t ha $\left.^{-1}\right)$, ICSA $38 \times$ SPV $422\left(2.1\right.$ t ha $\left.^{-1}\right)$, ICSA $84 \times$ SPV $1411\left(2.1\right.$ t ha $\left.^{-1}\right)$ and XSR 401 (2.1 t ha $\left.^{-1}\right)$ compared to the control CSH 15R (1.8 t ha-1), Parbhani Moti (1.5 t ha $^{-1}$ ), and M 35-1 (1.5 t ha-1) (Table 4). The hybrids ICSA 502 x SPV 422 and 8712 were stable across the environments with high mean, regression slope of one and non-significant $\delta^{2} \mathrm{di}$. Hence, both of these hybrids are suitable for general cultivation for overall environmental conditions and they are considered as stable genotypes for grain yield (Table 3). The hybrid XSR 401 had shown high mean, bi $>1$ with non-significant $\delta^{2} \mathrm{di}$. So, this hybrid is considered as below average in stability. Such genotypes tend to respond favourably to better environments but give poor yield in unfavourable environments. Hence, they are suitable for favourable environments.

Table 3. Regression coefficient and stability parameters for grain yield over three locations

\begin{tabular}{lrr}
\hline Hybrids & Regression coefficient (bi) & Stability parameters (2di) \\
\hline ICSA 84 X SPV 1411 & 0.662 & 1.497 \\
ICSA 675X SPV 1411 & 1.039 & 0.018 \\
ICSA 702 X SPV 1411 & 0.572 & -0.017 \\
ICSA 38 X SPV 422 & 0.873 & 0.041 \\
ICSA 502 X SPV 422 & 1.045 & 0.006 \\
ICSA 675 X ICSV 700 & 0.861 & 0.650 \\
ICSA 88001 X M 35-1-19 & 1.413 & 0.249 \\
ICSA 88001 X IS 33844-5 & 1.424 & 0.129 \\
8712 & 1.032 & 0.253 \\
XSR 401 & 1.404 & 0.299 \\
Parbhani Moti (Control) & 0.764 & -0.017 \\
M 35-1 (Control) & 0.880 & -0.001 \\
CSH 15R (Control) & 1.029 & 0.128 \\
\hline
\end{tabular}


For grain yield, seven hybrids performed significantly better over the control CSH 15R (1.8 t $\left.\mathrm{ha}^{-1}\right)$. All the selected hybrids were shown significant standard heterosis over controls ranged from 5.5 to $60 \%$ (Table 4). The plant height ranged from 1.9 to $2.3 \mathrm{~m}$. All the selected hybrids were 3 to 4 days earlier than M 35-1 and at par with CSH 15R. Hundred seed size ranged from 2.4 to $3.5 \mathrm{~g}$ and grain luster score ranged from 1 to 2 for all the hybrids. The shootfly dead hearts percentage ranged from 53 to 75 and the hybrid 8712 was at par with CSH 15R (55) for shootfly dead hearts percentage. The charcoal rot infection in the test hybrids ranged from 0.3 internode (ICSA 84 x SPV 1411) to 3.4 internodes (ICSA $20 \times$ ICSR 93009) and the soft rot ranged from 6 (ICSA $675 \times$ SPV 1411) to 100\% (ICSA $20 \times$ ICSR 93009).

Table 4. Pooled mean performance of selected advanced sorghum hybrids during postrainy season

\begin{tabular}{|c|c|c|c|c|c|c|c|}
\hline Hybrid & $\begin{array}{r}\text { Seed weight } \\
\left(\mathrm{g} 100^{-1}\right)\end{array}$ & $\begin{array}{r}\text { Plant height } \\
\text { (m) }\end{array}$ & $\begin{array}{r}\text { Days to } 50 \% \\
\text { flowering }\end{array}$ & Tuster & $\begin{array}{r}\text { Grain Yield } \\
\left.(\mathrm{t} \mathrm{ha})^{-1}\right)\end{array}$ & $\begin{array}{r}\text { Shootfly dead } \\
\text { hearts \% }\end{array}$ & Soft rot \% \\
\hline ICSA 502 X SPV 422 & 2.5 & 1.9 & 75 & 2 & 2.4 & 74 & 39 \\
\hline 8712 & 2.7 & 2.3 & 76 & 2 & 2.1 & 55 & 24 \\
\hline ICSA 38 X SPV 422 & 2.9 & 2.2 & 75 & 2 & 2.1 & 75 & 58 \\
\hline ICSA 84 X SPV 1411 & 3.0 & 2.2 & 80 & 1 & 2.1 & 69 & 39 \\
\hline XSR 401 & 3.2 & 2.2 & 75 & 2 & 2.1 & 59 & 6 \\
\hline ICSA 88001 X M 35-1-19 & 2.4 & 2.3 & 75 & 2 & 2.0 & 69 & 17 \\
\hline ICSA 88001 X IS $33844-5$ & 2.6 & 2.3 & 75 & 2 & 1.9 & 70 & 28 \\
\hline ICSA 675X SPV 1411 & 3.1 & 2.4 & 75 & 2 & 1.8 & 74 & 6 \\
\hline CSH 15R (Control) & 3.2 & 2.4 & 77 & 2 & 1.8 & 55 & 0 \\
\hline ICSA 675 X ICSV 700 & 2.8 & 2.3 & 77 & 2 & 1.7 & 67 & 6 \\
\hline M 35-1 (Control) & 2.6 & 2.2 & 79 & 2 & 1.5 & 53 & 22 \\
\hline Parbhani Moti (Control) & 2.7 & 2.3 & 80 & 1 & 1.5 & 64 & 29 \\
\hline ICSA 702 X SPV 1411 & 3.5 & 2.3 & 74 & 2 & 1.5 & 66 & 19 \\
\hline Mean & 2.9 & 2.2 & 76.5 & 1.7 & 1.9 & 65.5 & 27.4 \\
\hline SE & 0.2 & 11.6 & 1.2 & 0.3 & 0.2 & 6.6 & 15.1 \\
\hline $\mathrm{CV} \%$ & 11.5 & 8.4 & 2.6 & 26.2 & 12.0 & 15.6 & - \\
\hline Lsd (5\% level) & 0.5 & 32.8 & 3.4 & 0.7 & 0.4 & 19.0 & 43.6 \\
\hline
\end{tabular}

Based on number of nodes infected, infection length and per cent soft rot, two hybrids (ICSA 675 x SPV 1411 and ICSA 675 x ICSV 700) appeared tolerant to charcoal rot with $<1$ internode infection, length of infection $<5 \mathrm{~cm}$ and $<10 \%$ soft rot. Rainfed regions and semiarid tropics (SAT) are in the face of increasing population pressure and declining/ degrading natural resources (Cooper and Byth, 1996).

Table 5. Sorghum seed and pollen parent's performance for shootfly and grain yield

\begin{tabular}{clrr}
\hline S.No. & Hybrid Parents & Shootfly dead hearts \% & Grain yield (t ha $\left.{ }^{-1}\right)$ \\
\hline 1 & ICSB 84 & 100.0 & 1.7 \\
2 & ICSB 675 & 76.5 & 3.6 \\
3 & ICSB 702 & 94.4 & 2.8 \\
4 & ICSB 38 & 100.0 & 1.9 \\
5 & ICSB 502 & 87.5 & 1.3 \\
6 & ICSB 88001 & 76.67 & 3.8 \\
7 & ICSV 700 & 44.1 & 4.6 \\
8 & M 35-1-19 & 87.5 & 2.5 \\
9 & SPV 422 & 92.0 & 5.3 \\
10 & Parbhani Moti & 84.2 & 3.7 \\
11 & IS 33844-5 & 55.6 & 2.6 \\
\hline
\end{tabular}

Therefore, developing hybrids with wide environmental adaptation is very crucial in the present context. In the present study, the hybrid ICSA 502 x SPV 422, 8712, ICSA 38 x SPV 422, ICSA 84 x SPV 1411 and XSR 401 shows wide adaption with high heterotic potential across three environments for postrainy adaptation. Higher level heterosis in a cross always represents genetically more diverse parents than those crosses, which show little or no heterosis (Falconer et al., 1986 and Mungoma and Polloak, 1988). From the results, an appreciable level of heterosis over standard checks 
was evident for the characters under study (Table 6). In conclusion, ICSA 502 x SPV 422 was the highest yielder among the hybrids showing significant heterosis over all the three checks for grain yield and grain size. Its shootfly resistance was also at par with the hybrid, ICSA 38 x SPV 422.
Sorghum has a great production potential but traditional low-yielding materials are still preferred because their photoperiod sensitivity that helps them escape from excess moisture (panicle diseases) and enables flexible calendars (Dingkuhn, 2011) and possess farmer preferred traits. Sorghum is a short-day

Table 6. Heterosis over standard checks for selected sorghum hybrids during postrainy season

\begin{tabular}{|c|c|c|c|c|c|}
\hline \multirow[t]{2}{*}{ S.No. } & \multirow[t]{2}{*}{ Hybrids } & \multirow{2}{*}{$\begin{array}{l}\text { Grain Yield } \\
\qquad\left(\mathrm{t} \mathrm{ha}^{-1}\right)\end{array}$} & \multicolumn{3}{|c|}{ Heterosis over standard checks } \\
\hline & & & $\%$ over CSH 15R & $\%$ over M $35^{-1}$ & \% over Parbhani Moti \\
\hline 1 & ICSA 502 X SPV 422 & 2.4 & 33.3 & 60.0 & 60.0 \\
\hline 2 & 8712 & 2.1 & 16.6 & 40.0 & 40.0 \\
\hline 3 & ICSA 38 X SPV 422 & 2.1 & 16.6 & 40.0 & 40.0 \\
\hline 4 & ICSA 84 X SPV 1411 & 2.1 & 16.6 & 40.0 & 40.0 \\
\hline 5 & XSR 401 & 2.1 & 16.6 & 40.0 & 40.0 \\
\hline 6 & ICSA 88001 X M 35-1-19 & 2.0 & 11.1 & 33.3 & 33.3 \\
\hline 7 & ICSA 88001 X IS 33844-5 & 1.9 & 5.5 & 26.6 & 26.6 \\
\hline 8 & ICSA 675X SPV 1411 & 1.8 & 0.0 & 20.0 & 20.0 \\
\hline \multicolumn{6}{|c|}{ Controls } \\
\hline 9 & $\mathrm{CSH} 15 \mathrm{R}$ & 1.8 & - & - & - \\
\hline 11 & M 35-1 & 1.5 & - & - & - \\
\hline 12 & Parbhani Moti & 1.5 & - & - & - \\
\hline
\end{tabular}

plant (SDP), and variation in the response to photoperiod and temperature determines its adaptation to the wide range of different environments in which it is grown (Craufurdet al., 1999). In the present study all the selected hybrids were 3 to 4 days earlier than the popular variety, M 35-1 which is under cultivation since long time and also compared to the recently released variety, Parbhani Moti. To develop shootfly resistant hybrids, both parents (especially female parent) need to be improved for shootfly resistance (Reddy et al., 2010; Kumar et al., 2011).

Some of the hybrids lack tolerance to shootfly and grain quality traits like luster. The males being the selections from land races were less susceptible to shootfly unlike the females (Table 5). Same trend was observed with grain quality traits like luster. Therefore, there is a need to develop female lines with resistance to shootfly and with grain luster. Henceforth developing hybrid parents both males and females in different gene pools for postrainy season adaptation traits (shootfly resistance and grain luster) will lead to hybrids with high heterotic yield and greater adaptability in postrainy season with the desired level of consumer acceptance.

\section{Funding and Acknowledgment}

Financial support provided by the Bill and Melinda Gates Foundation in the form of HOPE Dryland Cereals Project is gratefully acknowledged.

\section{REFERENCES}

Brown, K.D., M.E. Sorrells and W.R. Coffman. 1983. A method for classification and evaluation of testing environments. Crop Sci, 23: 889-893.

Cooper, M and Byth, D.E. 1996. In: Plant adaptation and crop improvement. Page No. 5-24.

Craufurd, P. Q., Mahalakshmi, V, Bidinger, F.R, Mukuru, S.Z, Chantereau, J, Omanga, P.A, Qi, A, Roberts, E. H, Ellis, R. H, Summerfield, R.J and G.L. Hammer. 1999. Adaptation of sorghum: characterisation of genotypic flowering responses to temperature and photoperiod. Theor App/ Genet, 99:900-911.

Dingkuhn, M. 2011. In: International conference on Crop improvement, Ideotyping, and Modelling for African Cropping Systems under Climate Change - CIMAC at University of Hohenheim, 7-9 Feb, 2011, Page No. 5-8.

Eberhart, S.A. and W.A. Russell. 1966. Stability parameters for comparing varieties. Crop Sci, 6: 36-40. Falconer, D.S. and Mackay Trudy, F.C. 1986. In: Introduction to Quantitative Genetics. Longman Ltd. Harlow. England.

ICRISAT. 2001. Production and productivity trends of ICRISAT mandate crops. Information bulletin 356: $27 \mathrm{pp}$.

Jowett. D. 1971. Yield Stability Parameters for Sorghum in East Africa. Crop Sci, 12: 314-317.

Kumar, A. K., Belum V.S Reddy, HC Sharma, CT Hash, P Srinivasa Rao, B Ramaiah, and P Sanjana Reddy. 2011. Recent advances in sorghum genetic enhancement research at ICRISAT. American Journal of Plant Sciences, 2 (4): 589-600. 
Moreno-Gonzáles, J. and J.I. Cubero. 1993. Selection strategies and choice of breeding methods. In: M.D. Hayward, N.O. Bosemark\& I. Romagosa (Eds.): Plant Breeding: Principles and Prospects, pp. 81-313. Chapman \& Hall, London.

Mungoma, C. and Polloak, L.M. 1988. Heterotic patterns among ten Corn Belt and exotic populations.Crop. Sci., 28: 500-504.

Pham, H.N. and G.O. Edmeades. 1987. Delineating maize production environments in developing countries. In: CIMMYT Research Highlights 1986, pp.3-11.

Rao, N.G.P. 1970. Genetic analysis of some exotic $x$ Indian crosses in sorghum. I. Heterosis and its interaction with seasons. Indian Journal of Genetics and Plant Breeding, 30: 347-361.
Reddy, B.V.S. and Stenhouse J.W. 1994. Improving postrainy season sorghums: A case for landrace hybrids breeding approach. Paper presented at the All India Coordinated Sorghum Improvement Project (AICSIP) workshop held at GBPUAT, Pantnagar, U.P., April 18-20.

Reddy, B. V. S., Ashok Kumar, A and P. Sanjana Reddy. 2010. Recent Advances in Sorghum Improvement Research at ICRISAT. Kasetsart J. (Nat. Sci.) 44: 499-506.

Saeed M, C.A. Francis, J.F. Rajewski and J.W. Maranville. 1985. Genotype x Environment Interaction and Stability Analysis of Protein and Oil in Grain Sorghum. Crop Sci., 27: 169-171. 